\title{
Association of nitrogen-fixing microorganisms in the surface of nodules in wild perennial leguminous plants Onobrychis transcaucasica and Onobrychis chorassanica Umarov B.R.
}

Department natural science. Uzbek State World Language University, Tashkent, Uzbekistan E-mail:b.r.umarov@mail.ru

Key message. The results of molecular genetic analysis root nodule bacteria wild leguminous plants germinating in the Arid zones Central Asia can penetrate into various nitrogen-fixing microorganisms. Bacteria of plants Onobrychis transcaucasica and Onobrychis chorossanica origin are found bacteria in the class Alphaproteobacteria and some nitrogen-fixing bacteria which we are write were in the class of Betaproteobacteria.

Keywords: leguminous plants, Onobrychis, root nodule bacteria, molecular genetic analysis

Over 100 nitrogen-fixing microorganisms were isolated from the nodules of perennial wild leguminous plants Onobrychis transcaucasica and Onobrychis chorassanica growing in the desert territories of Uzbekistan. According to the results of a taxonomic analysis, the $16 \mathrm{~S}$ rDNA gene found that the isolated bacteria more than $50 \%$ belong to different types of nitrogenfixing bacteria. Nucleotide sequencing of the 16S rRNA gene and NCBI BLAST analysis showed in the nodule bacteria of Onobrychis plants were found many different nitrogen-fixing bacteria's, as Paenobacillius sp., Rhizobium, Burkholderia, Enterobacter and Pantoea.

It has been shown a possibility of growing up of Onobrychis plants at minimal additional moisture of sabulous soils in the Kyzyl Kum Desert, creating artificial pastures and thereby immobilizing the desert blown sands. Although more than on 32 million ha worldwide alfalfa is grown, it is conducted a search for new special purpose forage legumes supported by smaller plantings of species of Coronilla, Onobrychis, and Lotus.

In all studies on the isolation of bacteria from nodules, acetylene reduction assay, experiments with micro-vegetation, CTAB genomic DNA extraction were used by laboratory manual of the professor Sharon R. Long (http://longlab.stanford.edu/protocols.html). Molecular genetic analysis, a study with the PCR analysis, the selection of 16 rDNA primers, nodC, nifHF, ERIC, Box and other primers, as well as all the methods used, are described in research Laguerre et al. (2001).

The results of molecular genetic analysis root nodule bacteria (or in inside root nodule) wild leguminous plants germinating in the Arid zones Central Asia can penetrate into various nitrogen-fixing microorganisms. As revealed in our studies. According to NCBI BLASTN analysis and phylogenetic analysis, it is that bacteria of plants Onobrychis transcaucasica and Onobrychis chorossanica origin are found bacteria in the class Alphaproteobacteria and some nitrogen-fixing bacteria which we are write were in the class of Betaproteobacteria.

The author is grateful to the Dr. Ines Soares, BGU-Israel for conducting molecular genetic analysis of this work. 